\title{
恢复及演替过程中的土壤生态学考虑
}

\author{
朱伟兴 \\ (纽约州立大学-宾汉姆分校生物系,宾汉姆 NY 13902 美国)
}

摘 要 人类社会的日益扩张, 导致人类加速占据地球表面景观, 并胁迫地球上生态系统提供不断增长的资源需 求和废物吸收能力。所以保护尚未“开放”的自然生态系统及恢复退化的生态系统成为人类长期生存的重要保证。 该文着重讨论了恢复过程中的土壤生态学问题。土壤是所有陆地生态系统的结构与功能基础。土壤微生物与动 物的种群变化, 土壤有机质的积累, 及主要元素地球化学循环的改变是恢复生态的重要环节。生态恢复与演替有 许多共性, 所以演替理论对于认识生态系统恢复中的结构与功能变化有着很大帮助。与自然演替不同的是, 人的 积极参与在生态恢复中占有中心位置。从最初样地的确立与物种的选择, 到后续的灌溉与施肥管理, 人的选择影 响着土壤的演化, 生态系统的发展方向, 和最终恢复生态的结果。为保障恢复生态系统的可持续性, 短期的工作目 标, 如提供养分促进植物生长, 务必与长期的工作目标, 如土壤的恢复相结合。植物与土壤的相互反馈是生态恢复 成功的重要标志。成功的生态恢复不仅是对现有生态学理论的“试金检验”, 也是推动生态学学科发展的重要原动 力。

关键词 生态系统方法 土壤 植物-土壤反馈 恢复 可持续性

\section{CONSIDERATION OF SOIL ECOLOGICAL PROCESSES IN RESTORATION AND SUCCESSION}

\author{
ZHU Wei-Xing \\ (Deptartment of Biological Sciences, State University of New York-Binghamton, Binghamton, NY 13902, USA)
}

\begin{abstract}
The dominance of human society on earth is putting tremendous pressure on the earth's ecosystems for resources and waste assimilation. Conserving remaining “unexploited” natural ecosystems and restoring degraded ecosystems is a necessity for the long-term sustainability of humankind. Structurally, soil is the foundation of all terrestrial ecosystems and affects every ecosystem function. Unfortunately, degradation of soil by human activities is common. Understanding changes in soil microbial and invertebrate communities, organic matter accumulation, and how key biogeochemical cycling of nutrients are changed during ecosystem restoration is essential. Ecosystem restoration shares many similarities with natural succession, and therefore can benefit from the rich ecological understanding of the functional and structural changes that take place during succession. However, unlike naturally occurring succession, ecosystem restoration is manipulated through human intervention. Management decisions in restoration, including plant selection, site selection with consideration of soil parent material, topography and local climate, as well as fertilization, irrigation and other human interventions, heavily influence soil formation and soil processes, and thus affect successional trajectories and restoration. To make restored systems self-sustainable, strategies addressing short-term nutrient supply for quick plant growth and long-term soil development, and those promoting positive plant-soil feedbacks are needed. Not only is successful restoration an "acid test" of our current ecological theories, but it also contributes to the future development of our scientific discipline; thus it is both a challenge and an opportunity for professional ecologists.
\end{abstract}

Key words Ecosystem approach, Soil organic matter, Soil nutrient, Soil microbial organism, Plant-soil interaction, Sustainability, Ecosystem restoration

Received: 2004-11-02 Accepted: 2004-11-26

Foundation item: Supported by the Research Foundation of the State University of New York - Binghamton

Acknowledgement: This paper is based on the presentation at the "Succession Theory and Restoration Practices Workshop", in Guangzhou, China, December 2002, organized by South China Institute of Botany, the Chinese Academy of Science. Professor Joan Ehrenfeld provided comments on an early draft of the manuscript. I thank Scott Fickbohm and Jeffrey Bohner for the helpful comments on writing. The Chinese translation of Bradshaw's “acid test” was benefited from Prof. J. Enrenfled's English explanation and the discussion with Drs. Qinfeng Guo and Xingguo Han during the Guangzhou workshop

E-mail: wxzhu@ binghamton.edu 
In human-dominated earth landscapes, where dramatic changes in land use, global climate, key global biogeochemical cycles, and broad scale exotic species invasions threaten the integrity of various ecosystems, we urgently need to restore degraded ecosystems to their natural conditions (Dobson et al ., 1997). The human impact on the earth's ecosystems occurs on a variety of temporal and spatial scales. While catastrophic environmental accidents frequently catch the eye of the general public, anthropogenic related land-use changes that occur at the global scale have a much broader and sustained impact. Similarly, global elevation of atmospheric $\mathrm{CO}_{2}$ concentration, and its consequent effect on global warming, and global alterations of key biogeochemical cycles such as nitrogen $(\mathrm{N})$ cycle are chiefly due to daily human consumption of fossil fuels and fertilizer production/usage ( Vitousek, 1994). Such environmental changes, occurring at global scale, interact with each other and negatively affect ecosystem structure and function (Vitousek et al., 1997).

Ecological restoration means restoring both ecosystem structure, including species composition and trophic interactions, and ecosystem function, including key ecosystem processes and various biogeochemical pools, to a state comparable to the original (Bradshaw, 1996). Soil is a fundamental component in every terrestrial ecosystem, making soil restoration a vital process during ecological restoration; however, this fact has been frequently overlooked. In this paper, I have outlined an ecosystem-based approach for restoration, discussed in particular soil modifications and plant-soil interactions during restoration, and argue for a self-sustained system as the ultimate goal of ecological restoration.

\section{Types and goals of ecological restoration and the comparison to natural succession}

Restoration starts at degraded systems with impaired structure and function due to anthropogenic or natural causes. While it is frequently stated that both structure and function should be restored (by definition of restoration: "to bring back to the original state, or to a healthy or vigorous state”, Oxford English Dictionary), functional restoration is usually required prior to restoring structural complexity (Fig. 1). In many practices, making the land fit for cultivation, or reclamation is the goal. In some cases the function of the system was largely unaltered (e.g., the invasion of exotic species can greatly reduce native biodiversity but has little impact on ecosystem processes such as primary production), here, restoring structural complexity is the goal. Thus, depending on the priorities set for structural and functional restoration, efforts could have different goals. And in some circumstances, due to continuous human interference, either directly to the system or indirectly from the surrounding landscape, restoration may never be able to fully reach the original state (Ehrenfeld, 2000).

The multiple aspects of restoration

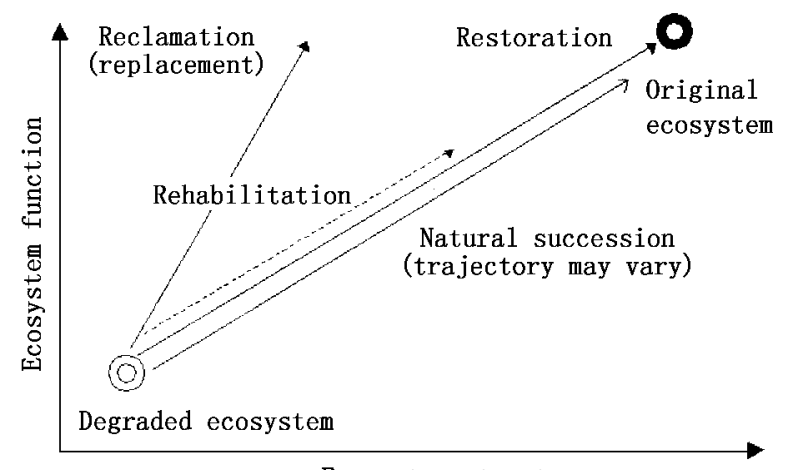

Ecosystem structure

Fig. 1 Types and goals of restoration Adopted from Bradshaw (1996), with modifications

Nature has its own way of dealing with degraded systems. Succession is a directional change over time in ecosystem structure and function after a disturbance. Usually this involves simple systems progressing through complex stages brought about by changes in resource supply (light, nutrient, etc.) and biological interactions. However, a system may not necessarily go back to its exact pre-disturbance conditions (trajectory may vary, Fig. 1) since many factors could affect the processes of succession. Restoration differs from succession because of explicit human involvement to 1 ) shorten the time of recovery, 2) set the initial recovery conditions, and 3) control the recovery trajectories so "desired" structure and function can be achieved. Alternatively, natural succession frequently takes hundreds of years and its end stages may not fit well in a landscape dominated by humans. Since most " real-world" restorations have resource limitation and could not achieve the perfect goal of functional and structural recovery, they frequently initiate "the action of restoring a thing”, or rehabilitation (Bradshaw, 1996).

In the natural world, succession can be classified as primary or secondary due to the extent of pre-succession disturbance. Since we can view restoration as a special kind of succession with strong human involvement, we can separate restoration practices accordingly (primary or secondary scenarios). Human and natural disturbances may have degraded a system to such an extent that the original soil has been depleted or substantially altered (a landslide, for example). Under such scenarios, primary succession or a primary succession type of restoration, can 
take place. Soil restoration and the recovery of key ecosystem functions, one big concern in this type of restoration, depend on the accumulation of soil organic matter, essential nutrients, and the establishment of soil microbial community. Alternatively, some disturbances may not go that far, leaving the original soil, plant seed banks and extensive root systems largely intact (such as after a clear-cut or a forest fire). Under such conditions, recovery can occur rather quickly and follow the route of secondary succession. A secondary succession type of restoration should focus more on structure recovery, native species diversity, and complex species interactions.

The ultimate goal of restoration is to reach some "self-sustainable" stage where human assistance can be minimized or removed. British ecologist Tony Bradshaw challenged professional ecologists more than 20 years ago to be more involved in the field of restoration ecology, and called restoration the "acid test" of our ecological understanding (Bradshaw, 1987). Such a high bar in academic achievement remains an embedded goal of restoration ecology .

\section{Ecosystem approach}

Since no organism can be successfully restored without its supporting environment, restoration, regardless of its type and goal, should be ecosystem based. Large amounts of material export frequently characterize a degraded system, such as following a forest clear-cut (Likens \& Bormann, 1995). Systems under extreme degradation without much biological structure (i.e. landslides) can experience copious energy and material inputs and outputs, with minimal internal usages and transformations of materials (cycling). It is up to the establishment of a functional biological community ( especially vegetation) to make use of the material input and minimize its output (Odum, 1969). An ecosystem can be defined as a basic unit of nature, that is, a spatially explicit unit of the earth that includes all organisms along with all components of the abiotic environment within its boundaries (Likens, 1992). For restoration practices, this means the buildup of primary producers, consumers, decomposers, and their interactions as well as the modification of abiotic conditions in the system. Restoration should also facilitate the establishment of detritus pools and nutrient cycling and promote their feedbacks with biological entities. In addition, landscape connectivity and disturbance regimes play essential roles in shaping restoration within the targeted system. Modern ecosystem concept emphasizes the dynamic nature of ecosystem development (Pickett \& Cadenasso, 2002). Applying this to restoration ecology means that ecological research should not be restricted to mature systems, or so-called " climax systems"; rather, it should emphasize the study of ecosystem development (i.e., the development of structure and function, from degraded stages to advanced self-sustained stages), in order to understand species interactions, the controlling factors involved in ecosystem development, and various feedbacks both within and between biotic and abiotic components (Pickett \& Parker, 1994; Ehrenfeld \& Toth, 1997; Suding et al., 2004).

\section{Restoring soil as a major component of e- cosystem restoration}

Soil is a multi-phase entity consisting of solids, liquids, and gases. The physical soil matrix provides a source of water and nutrients to plants and soil organisms and is the physical supporting system where terrestrial vegetation is rooted. In primary succession, soil is developed gradually through the weathering of parent material, addition of detritus material from plants, animals, and microbes, and transformation and transfer of various elements down and up along the soil profile. Additionally, loss of materials from the system through leaching and surface erosion is also characteristic. Poorly developed soil is not expected to support a forest with diverse and dense plant populations, although such soil may well support certain pioneer species. The feedbacks between plant and soil lead to the accumulation of organic matter, nutrients, and microbial populations, which result in the buildup of a developed soil. Even with pioneer species, the application of fertilizers (organic or inorganic forms) can usually speed up plant growth, increase plant-soil feedbacks, and promote a faster system restoration.

In secondary succession types of restoration, initial soil may remain intact and plant re-growth usually occurs quickly. Still, plant-soil interactions can affect soil development and plants selected for restoration frequently affect soil properties. In a study of a plantation forest on abandoned agricultural fields in south-central New York, USA, different tree species, including red oak (Quercus rubra), red pine (Pinus resinota), sugar maple (Acer saccharum), Norway spruce ( Picea abies), and black locust (Robinia pseudoacacia), were found to have very different effects on the development of soil profile including difference in organic matter accumulation ( $\mathrm{x} 2$ difference), net $\mathrm{N}$ mineralization rate (species mean from 0.99 to $2.14 \mu \mathrm{g} \mathrm{N} \cdot \mathrm{g}^{-1}$ soil $\left.\bullet \mathrm{d}^{-1}\right)$, and net nitrification rates ( from 0.08 to $1.87 \mu \mathrm{g} \mathrm{N} \cdot \mathrm{g}^{-1}$ soil $\bullet \mathrm{d}^{-1}$ ), 60 years after the trees were planted ( $\mathrm{Zhu}$, unpub. data). Thus, even under secondary succession scenarios, plant composition can have a drastic impact on soil development.

\subsection{Soil organic matter}

Soil organic matter (SOM), in succession or restoration, accumulates due to the imbalance between detritus production and decomposition. Approximately $90 \%$ of net 
primary production $(N P P)$ in forest ecosystems eventually enters soil as leaf, root, and wood (Chapin et al., 2002). Soil microbial organisms carry out the processes of decomposition and are not readily separated from the litter material. SOM, thus by definition, comprises partially decayed plant residues, microbial organisms, small fauna involved in decomposition, and the byproducts of decomposition (Paul \& Clark, 1996). Decomposition byproducts undergo the process of humification and contribute to the long-term $\mathrm{C}$ and $\mathrm{N}$ storage in terrestrial ecosystems. From the perspective of restoration, SOM accumulation leads to many changes in soil properties including soil texture, formation of aggregate structure, reduction of bulk density, stabilization of soil $\mathrm{pH}$ (buffer capacity), and increases in water holding capacity and cation exchange capacity (CEC, Table 1). All these could positively affect plant growth, which provides a further substrate for SOM accumulation. Soil microbial organisms reside in the organic matrix, thus SOM accumulation usually leads to the increase of microbial biomass, in addition to the accumulation of organic $\mathrm{C}$ and organic $\mathrm{N}$.

In a study of forest restoration after landslide events (a primary succession scenario), Singh et al. (2001) documented many changes in soil. Along with a 3.2 fold accumulation of SOM from a 1-year-old site to a 58-yearold site, soil total $\mathrm{N}$ increased 2.8 fold, while sand fraction reduced from $85 \%$ to $49 \%$ and clay fraction increased from $6.5 \%$ to $20 \%$. Additionally, maximum water holding capacity increased from $25 \%$ to $52 \%$, while total phosphorus and extractable Ca both increased 2.2 fold (Fig. 2). In general, SOM content gradually increases under primary succession scenarios and levels off during the later stages of succession. Net ecosystem production ( NEP ) peaks in the middle of succession and contributes to the accumulation of both living organisms (plants, animals, and microbial decomposers) and the dead organic matter ( both above-ground and belowground).

SOM accumulation depends on plant primary production. Restoration ecologists frequently select grasses and other fast growing plants (including many legume species) to grow on degraded soils to foster SOM accumulation ( Table 1). Factors that benefit pioneer plants during primary production such as fertilization and irrigation (if needed) can effectively increase initial SOM accumulation. The choice of mulch or top-soil amendments can also enhance soil water and nutrient retention, increase soil fertility, as well as increase SOM directly because of the organic matter contained therein. In a mine soil restoration in eastern USA, for example, wood chip amendments significantly increased pine seedling growth, soil water potential, total $\mathrm{N}$, organic $\mathrm{C}$, and $\mathrm{N}$ mineralization rates 3 years after restoration (Schoenholtz et al., 1992).

In secondary successions, SOM change is usually minor since original soils are relatively undisturbed. This is true after forest clear-cuts if re-vegetation is allowed to occur immediately. On the other hand, when planting new tree species, the content and distribution of SOM

Table 1 Key soil indices and their changes during restoration

\begin{tabular}{|c|c|c|c|}
\hline & Changes during restoration & Effects on ecosystem structure and function & Restoration strategy \\
\hline $\begin{array}{l}\text { Soil organic } \\
\text { matter (SOM) }\end{array}$ & $\begin{array}{l}\text { Increase in primary succession types } \\
\text { of restoration. } \\
\text { Minor change in secondary succes- } \\
\text { sion scenarios. }\end{array}$ & $\begin{array}{l}\text { Improves soil texture, micro-structure, } \mathrm{pH} \text {, bulk } \\
\text { density, water holding capacity, etc. } \\
\text { Reduces soil erosion and increases nutrient reten- } \\
\text { tion. } \\
\text { Benefits soil microbial growth and the accumulation } \\
\text { of } \mathrm{N} \text { capital. } \\
\text { Benefits plant growth and the accumulation of organic } \\
\text { carbon. }\end{array}$ & $\begin{array}{l}\text { Establish pioneering plants. } \\
\text { Establish microbial symbiotic relationship } \\
\text { ( } \mathrm{N} \text { fixation, mycorrhizae) with plants. } \\
\text { Fertilizing to increase primary production. } \\
\text { Amending organic carbon through top-soil } \\
\text { transfer, mulching, and sluggish addi- } \\
\text { tion. }\end{array}$ \\
\hline Soil nutrients & $\begin{array}{l}\text { Limited in the early stages of prima- } \\
\text { ry succession scenarios. } \\
\text { Nutrient cycling/input ratios in- } \\
\text { crease. } \\
\text { Usually not limited in 2nd succes- } \\
\text { sion scenarios. }\end{array}$ & $\begin{array}{l}\text { Enhances ecosystem production. } \\
\text { Enhances carbon and nitrogen accumulation and cy- } \\
\text { cling. } \\
\text { Affects species interactions including mutualistic } \\
\text { symbiotic relationships. }\end{array}$ & $\begin{array}{l}\text { Apply inorganic fertilizers. } \\
\text { Apply organic nutrients. } \\
\text { Establish N-fixing plants. } \\
\text { Establish mycorrhizal symbionts to en- } \\
\text { hance nutrient uptake by plants. } \\
\text { Add high } \mathrm{C}: \mathrm{N} \text { material (like woodchips) } \\
\text { to assimilate excess nutrients. }\end{array}$ \\
\hline Soil organisms & $\begin{array}{l}\text { Increase in biomass and composition } \\
\text { in primary succession scenarios. } \\
\text { Composition changes in } 2 \text { nd succes- } \\
\text { sion scenarios. }\end{array}$ & $\begin{array}{l}\text { Forms mutualistic or symbiotic relationships with } \\
\text { plants. } \\
\text { Increases ecosystem complexity. } \\
\text { Increases nutrient turnover. } \\
\text { Increases nutrient retention. }\end{array}$ & $\begin{array}{l}\text { Inoculate commercially produced benefi- } \\
\text { cial microbial species. } \\
\text { Transfer top-soil from mature ecosystems. } \\
\text { Increase plant diversity to boost microbial } \\
\text { diversity. }\end{array}$ \\
\hline
\end{tabular}




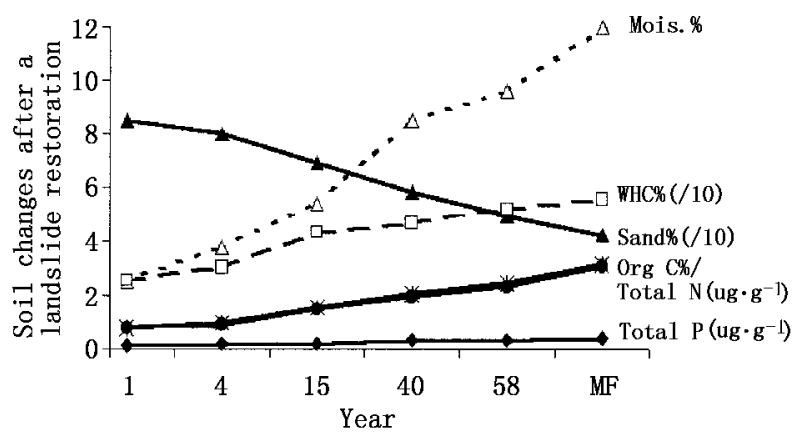

Fig. 2 Changes of soil properties in a natural restoration in the Himalaya landslide sites, described as a function of site age in years

MF: Mature reference forest Created based on the data in Singh et al . (2001) Certain soil parameters expressed with adjusted scales

may largely reflect the characteristics of the new species (Binkley \& Giardina, 1998). For example, coniferous trees with high $\mathrm{C}: \mathrm{N}$ ratio litter tend to decompose slowly and large quantities of organic matter are accumulated on the soil surface (mor type soils). On the other hand, deciduous trees such as birch and maple have leaf litter that is easily decomposed leaving organic matter more evenly distributed in the A-horizon (mull type soils).

\subsection{Soil nutrients}

The nutrient conditions of terrestrial ecosystems are affected by nutrient input, nutrient loss, and the nutrient cycling within the system. However, the accumulation of large quantities of organic matter (e.g., those in coniferous forests) may contribute little to the increase of soil nutrients. In a study of the Austrain black pine ( Pinus nigra ssp. nigra) plantation in southwestern Alps, soil fertility remains very poor with total $\mathrm{N}<0.3 \%, 120$ years after the initial site establishment (Vallauri et al ., 2002). Here, the accumulation of litter detritus was actually due to the lack of nutrients, which contributes to the slow decomposition. During ecosystem succession and related restoration practices, the accumulation of nutrient capitals is strongly affected by the biological species involved. This is especially true for $\mathrm{N}$ which is arguably the most important nutrient in terrestrial ecosystems.

Nitrogen accumulates in early stages of primary succession mainly through the retention of various $\mathrm{N}$ inputs including atmospheric depositions, and $\mathrm{N}$ fixations by legume and other species (Table 1). Vitousek and Reiners (1975) proposed that ecosystems in early succession should retain most of the $\mathrm{N}$ inputs to support plant growth; that $\mathrm{N}$ capital reaches equilibrium in old growth forests where output balances input. Recent studies demonstrated the importance of dissolved organic $\mathrm{N}$ (DON) in leaching export (Hedin et al., 1995) and elevated $\mathrm{N}$ deposition from anthropogenic sources could shorten the process of $\mathrm{N}$ accumulation and bring the system to a saturation stage that leads to $\mathrm{N}$ loss (Aber et al., 1998).

van Cleve et al . (1993) described the change of $\mathrm{N}$ availability during a primary succession in the floodplains of Alaska, USA. The colonization of the site by pioneer species such as willow resulted in an initial accumulation of SOM. However, it was not until the invasion of a species capable of actinorhizal $\mathrm{N}$ fixation, alder (Alnus tenuifolia), then the available $\mathrm{N}$ pool was more than tripled (Fig. 3). Following $\mathrm{N}$ inputs and accumulation, plant uptake of inorganic $\mathrm{N}$ and return of organic $\mathrm{N}$ in litter, coupled with microbial transformations of organic $\mathrm{N}$ to inorganic $\mathrm{N}$ ( $\mathrm{N}$ mineralization), a relatively closed $\mathrm{N}$ cycle was then formed. During the alder-poplar stage, surface layer inorganic $\mathrm{N}$ was dominated by $\mathrm{NO}_{3}^{-}$, produced through microbial mediated nitrification (Fig. 3). When balsam poplar ( Populus balsamifera) gradually replaced the alder, soil inorganic $\mathrm{N}$ became dominated by $\mathrm{NH}_{4}{ }^{+}$, which greatly reduced $\mathrm{N}$ leaching loss. Later studies suggested that poplar invasion may alleviate the soil C limitation, which increased microbial $\mathrm{N}$ immobilization and reduced the amount of $\mathrm{NH}_{4}^{+}$available for nitrification (Clein \& Schimel, 1995).

Restoration practices worldwide include planting $\mathrm{N}$ fixing species during the early stages of succession (Table 1). For example, in a project conducted in central Illinois, USA, the introduction of alder and another actinorhizal N fixation species, Elaeagnus umbellata, significantly increased soil $\mathrm{N}$ concentrations and increased the growth of black walnut (Juglans nigra) seedlings $2-3$ times more than the control (Friedrich \& Dawson, 1984).

In secondary successions, initial soil disruption is usually small. Nutrient loss after forest clear-cuts, for example, can be effectively stopped with the quick regrowth of new plants. Various steps can be taken to further minimize nutrient loss. Vitousek and Matson (1985) reported that practices leaving large amount of detritus on site, which promote microbial immobilization of available nutrients, can greatly reduce the $\mathrm{N}$ loss after cutting. Fertilization in secondary succession forests, however, may not achieve the desired result. Elevated nutrient supply may alter the interspecific competition and change the trajectory of restoration. Fahey et al . (1998) for example, reported that fertilizing enhanced the growth of the early succession species pin cherry (Prunus pensylvanica) and sustained its existence into later successional stages. This pioneer species has the most pronounced response to $\mathrm{N}$ fertilizing, with increased foliar nutrient concentrations and higher specific leaf area, which gives it advantages against its principle competitor, paper birch (Betula papyrifera), and later successional species such as American beech (Fagus grandifolia). 


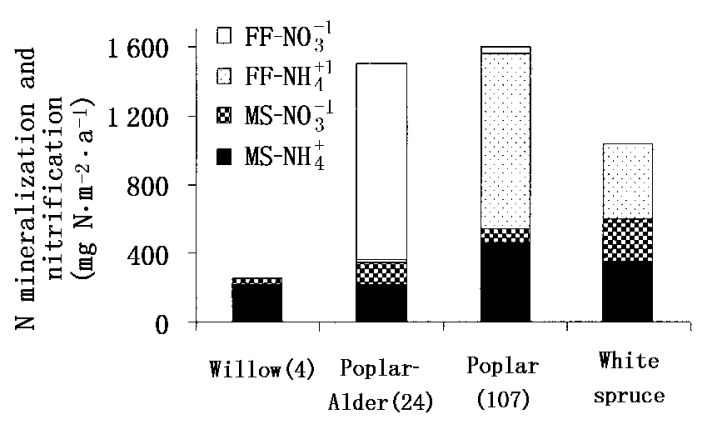

Fig.3 Accumulation and transformations of soil $\mathrm{N}$ in the forest floor ( FF) and mineral soil (MS) in a primary succession series in Alaska floodplain

The age (year) of the succession is shown in parenthesis after the dominant plant type. Created based on the data in van Cleve et al. (1993)

\subsection{Soil microorganisms}

Ecosystem degradation not only affects the conditions of soil organic matter and nutrients, but also affects the composition and abundance of soil microorganisms (Table 1). Under extreme conditions, such degradation causes the permanent loss of key indigenous microbial species, negatively affects plant-soil interactions, and makes restoration difficult. Vance and Entry (2000) compared soil properties between barren sites in the Siskiyou Mountains, Oregon, USA, where previous over-grazing and soil erosion leaves openings sparsely populated by forbs, shrubs, and the adjunct Shasta red fir (Abies magnifica var. shastensis). They found not only essential soil chemicals such as $\mathrm{C}, \mathrm{N}, \mathrm{K}, \mathrm{Ca}$ and $\mathrm{Mg}$ were significantly lower in barren soils, but also soil microbial biomass and enzyme activities were much lower in barren soil without forest cover. In the New Jersey Pinelands located in the eastern coast of USA, there exist persistent forest openings ("barren for decades"). It was found that the thickness of forest floor, root biomass, soil chemistry and soil fungal biomass in "barren sites" were several folds lower than that in the surrounding forest matrix (Ehrenfeld et al., 1995).

Human assisted microbial recolonization may be needed in restoring degraded ecosystems (Table 1). Requena et al. (2001) reported a restoration project in a desertified ecosystem in southeastern Spain ( annual rainfall $218 \mathrm{~mm}$, average yearly temperature $18{ }^{\circ} \mathrm{C}$ ) whereby introduction of indigenous arbuscular mycorrhizal ( AM) fungi and rhizobial $\mathrm{N}$-fixation bacteria successfully boosted native legume plant growth and improved various soil qualities. Both $\mathrm{N}$ transfer from legume shrubs to nonlegume plants and the overwhelming AM effort were documented in this restoration study. More than $90 \%$ of earthrooted plants form some type of mycorrhizal symbiosis (Allen, 1991). Mycorrhizal fungi can greatly enhance the uptake and use of $\mathrm{N}$ and $\mathrm{P}$ in soil, and are essential in species interactions belowground (protecting against root pathogens, for example) and in shaping aboveground plant competition and community composition (Allen et al., 1995).

In the processes of restoration and succession, not only does soil microbial complexity tend to increase, but also the absolute quantity of microorganisms, or microbial biomass, goes up. In the previous example of the landslide restoration (Singh et al ., 2001), microbial biomass $\mathrm{C}$, N, and $\mathrm{P}$ ( MB-C, MB-N, and MB-P) all increased 5 fold from the year-1-site to year-58-site, with biggest increment occurring at the early stages of the succession ( 1 -4 years, followed by $4-15$ years). Microbial biomass increase is important to soil fertility, especially to $\mathrm{N}$ supply. In soil, more than $90 \%$ of $\mathrm{N}$ is typically locked in humus with slow turnover rates and depends on microbial mediated mineralization to be released as inorganic $\mathrm{N}$ (Paul \& Clark, 1996). With N content typically more than 10 times the inorganic $\mathrm{N}$, microbial biomass is both an important soil $\mathrm{N}$ pool and facilitates important ecosystem functions such as temporal N retention (Zhu \& Carreiro, 2004). With the accumulation of microbial biomass and microbial complexity, invertebrate populations can build up and regulate microbial activities. Along with plant root systems (both live and dead), these populations will eventually form a complex soil biological community (Coleman \& Crossley, 1996).

\section{Plant-soil interactions}

Plant-soil interaction is the most important feedback in the processes of restoration and succession. The longterm accumulation of SOM, nutrient retention, and the buildup of microbial biomass ultimately depends on the $\mathrm{C}$ supply from plant primary production. In contrast to nutrient limitation in plant growth, soil microbes are largely C limited (Paul \& Clark, 1996). In analyzing 13 late-successional ecosystems across North America, Zak et al. (1994) measured microbial biomass C ( MBC) and N (MBN) and found good linear correlation between MBC and aboveground net primary production ( ANPP, $r^{2}=$ $0.51, p=0.006)$. The linear correlation between MBN and ANPP was also significant $\left(r^{2}=0.56, p=\right.$ 0.003 ).

Because $\mathrm{C}$ input from plant primary production is so important to soil development and soil development is vital to successive plant growth, many fast growing, pioneer plants have been introduced in restoration projects. However, since a diversified plant community affects soil microbial diversity and structural complexity, and soil processes ultimately affect the whole ecosystem structure and function, such a strategy should be judged as an initial step of restoration. In the previous example of the Alps pine restoration (Vallauri et al ., 2002), while the initial 
plantation of Austrian black pine successfully reduced soil erosion, 120 years later, the entire plant community still resembled an early developmental stage, with the black pine as the sole canopy species. Although the soil depth has been recovered, the soil structure remains simple and soil fertility is very low. The black pine monoculture also induces large-scale mistletoe infestations. Similar concerns about plant diversity were also raised in a bottomland restoration in the southern part of the USA (Allen, 1997). In southern China, Pinus massoniana has been widely used to restore vegetative cover and frequently forms large monotypic patches with very low species and structural diversity. Such simplified systems are vulnerable to pest/pathogen invasions, making additional restoration efforts necessary ( Yu \& Peng, 1996).

One restoration approach is to simultaneously restore functional processes and structural diversity. In restoration projects on former municipal landfill wastelands in New York City, Handel and his colleagues took a different approach (Handel et al., 1997; Robinson \& Handel, 2000). They selected native trees and shrubs to form clusters of "Habitat Islands" to attract birds for seed dispersal from nearby remnants of natural habitat. While the main focus of their studies was on seed recruitment and seedling survivorship and growth, the diverse plant composition within the established plots, and natural establishment outside the plots, makes possible the formation of a structurally complex soil system, including both key biogeochemical cycles and microbial populations.

\section{The long term sustainability of ecological restoration}

We currently live in a human-dominated earth with intensive and persistent human activities threatening the sustainability of the earth's life support systems (Vitousek et al ., 1997). Sustainability, in a broad sense, means "management practices that will not degrade the exploited systems or any adjacent systems", or implies "( human) consumption standards that are within the bounds of ecological possibility" (Lubchenco et al ., 1991). From that definition, restoring degraded systems and conserving those yet to be exploited at a global scale are urgently needed to maintain the earth's sustainability (Dobson et al., 1997).

From the perspective of restoring a particular ecosystem, sustained systems require minimal subsidization and are relatively self-sufficient. However, where most natural ecosystems are self-sufficient, most man-made systems, including restored ones, are not. Restoration ecology faces challenges to restore such sustainability and doing so requires our thorough understanding of ecological principles and their best applications in specific ecosystems
("Acid test", Bradshaw, 1987, 1996; "Ecosystem perspective”, Ehrenfeld \& Toth, 1997). This must include a thorough understanding of soil changes during the course of restoration. No natural ecosystems are stagnant; temporal variability or dynamics are an inherent part of ecosystem properties. Most natural ecosystems, however, do maintain certain stability. They are either resistant to change under perturbation, or return quickly to their original state after disturbance (are resilient). Resistance and resilience are important ecosystem properties and are affected by numerous interactions both within the system, and via landscape connections, with surrounding ecosystems (Suding et al ., 2004). Essentially, both resistance and resilience require a functionally integrated and structurally complicated soil system. Through the processes of restoration, as live plant based trophic systems ( herbivory) and detritus based trophic systems (decomposition) become established and diversified, so will various symbiotic relationships, couplings between production and decomposition, and between nutrient uptake and mineralization. All these will contribute to the stability of the restored ecosystem, affect its resistance and resilience, and determine the long-term sustainability of our restoration efforts .

\section{Reference}

Aber J, McDowell W, Nadelhoffer K, Magill A, Berntson G, Kamakea M, McNulty S, Currie W, Rustad L, Fernandez I (1998). Nitrogen saturation in temperate forest ecosystems: hypotheses revisited. BioScience, 48,921 - 934 .

Allen EB, Allen MF, Helm DJ, Trappe JM, Molina R, Rincon E (1995). Patterns and regulation of mycorrhizal plant and fungal diversity. Plant and Soil, 170, 47-62.

Allen JA (1997) . Reforestation of bottomland hardwoods and the issue of woody species diversity. Restoration Ecology, 5, 125 134 .

Allen MF (1991). The Ecology of Mycorrhizae. Cambridge University Press, Cambridge.

Binkley D, Giardina C (1998). Why do tree species affect soils? The warp and woof of tree-soil interactions. Biogeochemistry, 42, $89-106$.

Bradshaw AD (1987). Restoration: an acid test for ecology. In: Jordan III WR, Gilpin ME, Aber JD eds. Restoration Ecology: a Synthetic Approach to Ecological Research. Cambridge University Press, Cambridge. 23 - 29.

Bradshaw AD (1996). Underlying principles of restoration. Canadian Journal of Fisheries and Aquatic Sciences, 53 (S1) , 3-9.

Chapin III FS, Matson PA, Mooney HA (2002). Principles of Terrestrial Ecology. Springer, New York.

Clein JS, Schimel JP (1995). Nitrogen turnover and availability during succession from alder to poplar in Alaskan taiga forests. Soil Biology \& Biochemistry, 27, 743 - 752 .

Coleman DC, Crossley DA Jr (1996). Fundamentals of Soil Ecology. Academic Press, San Diego.

Dobson AP, Bradshaw AD, Baker AJM (1997). Hopes for the fu- 
ture: restoration ecology and conservation biology. Science, 277, 515 - 522 .

Ehrenfeld JG (2000). Defining the limits of restoration: the need for realistic goals. Restoration Ecology, 8, 2-9.

Ehrenfeld JG, Toth LA ( 1997). Restoration ecology and the ecosystem perspective. Restoration Ecology, 5, 307 - 317 .

Ehrenfeld JG, Zhu W, Parsons WFJ (1995). Above- and belowground characteristics of persistent forest openings in the New Jersey Pinelands. Bulletin of the Torrey Botanical Club, 122, 298 305 .

Fahey TJ, Battles JJ, Wilsons GF (1998). Responses of early successional Northern hardwood forests to changes in nutrient availability. Ecological Monographs, 68, 183-212.

Friedrich JM, Dawson JO (1984). Soil nitrogen concentration and Juglans nigra growth in mixed plots with nitrogen-fixing Alnus, Elaeagnus, Lespedeza, and Robinia species. Canadian Journal of Forest Research, 14, $864-868$.

Handel SN, Robinson GR, Parson WFJ, Mattei JH ( 1997 ). Restoration of woody plants to capped landfills: root dynamics in an engineered soil. Restoration Ecology, 5, 178 - 186.

Hedin LO, Armesto JJ, Johnson AH (1995) . Patterns of nutrient loss from unpolluted, old-growth temperate forests: evaluation of biogeochemical theory. Ecology, 76, 493 - 509.

Likens GE (1992). The Ecosystem Approach: Its Use and Abuse. Ecology Institute, Luhe.

Likens GE, Bormann FH (1995) . Biogeochemistry of a Forested Ecosystem. 2nd edn. Spinger-Verlag, New York.

Lubchenco J, Olson AM, Brubaker LB, Carpenter SR, Holland MM (1991). The sustainable biosphere initiative: an ecological research agenda. Ecology, 72, 371-412.

Odum EP (1969). The strategy of ecosystem development: an understanding of ecological succession provides a basis for resolving man's conflict with nature. Science, 164,262-270.

Paul EA, Clark FE (1996). Soil Microbiology and Biochemistry. 2nd edn. Academic Press, New York.

Pickett STA, Parker VT (1994) . Avoiding the old pitfalls: opportunities in a new discipline. Restoration Ecology, 2, $75-79$.

Pickett STA, Cadenasso ML (2002). The ecosystem as a multidimensional concept: meaning, model and metaphor. Ecosystems, 5, $1-10$.

Requena N, Perez-Solis E, Azcón-Aguilar C, Jeffries P, Barea J (2001) . Management of indigenous plant-microbe symbioses aids restoration of desertified ecosystems. Applied and Environmental Microbiology, 67, 495 - 498 .

Robinson GR, Handel SN (2000). Directional spatial patterns of recruitment during an experimental urban woodland reclamation. Ecological Application, 10, 174 - 188 .

Singh KP, Mandal TN, Tripathi SK (2001). Patterns of restoration of soil physicochemical properties and microbial biomass in different landslide site in the sal forest ecosystem of Nepal Himalaya. Ecological Engineering, 17, 385 - 401 .

Suding KN, Gross KL, Houseman GR (2004). Alternative states and positive feedbacks in restoration ecology. Trends in Ecology and Evolution, 19, $46-53$.

Schoenholtz SH, Burger JA, Kreh RE (1992). Fertilizer and organic amendment effects on mine soil properties and revegetation success. Soil Science Society of America Journal, 56, 1177 1184 .

van Cleve K, Yarie J, Erickson R, Dryness CT (1993). Nitrogen mineralization and nitrification in successional ecosystems on the Tanana River floodplain, interior Alaska. Canadian Journal of Forest Research, 23, 970 - 978.

Vallauri DR, Aronson J, Barbero M (2002) . An analysis of forest restoration 120 years after reforestation on badlands in the southwestern Alps. Restoration Ecology, 10, 16- 26.

Vance NC, Entry JA (2000). Soil properties important to the restoration of a Shasta red fir barrens in the Siskiyou Mountains. Forest Ecology and Management, 138, 427 - 434 .

Vitousek PM (1994). Beyond global warming: ecology and global change. Ecology, 75, $1861-1876$.

Vitousek PM, Reiners WA (1975). Ecosystem succession and nutrient retention: a hypothesis. BioScience, 25, 376-381.

Vitousek PM, Matson PA (1985). Disturbance, nitrogen availability, and nitrogen losses in an intensively managed loblolly pine plantation. Ecology, 66, 1360-1376.

Vitousek PM, Mooney HA, Lubchenco J, Melillo JM (1997). Human domination of earth's ecosystems. Science, 277, 494 499.

Yu ZY, Peng SL (1996) . Ecological Studies on Vegetation Rehabilitation of Tropical and Subtropical Degraded Ecosystems. Guangdong Science \& Technology Press, Guangzhou. (in Chinese)

Zak DR, Tilman D, Parmenter RR, Rice CW, Fisher FM, Vose J, Milchunas D, Martin CW (1994). Plant production and soil microorganisms in late-successional ecosystems: a continental-scale study. Ecology, 75, $2333-2347$.

Zhu WX, Carriero MM (2004). Soluble organic nitrogen and microbial nitrogen dynamics in deciduous forest soils: neglected segments of the nitrogen cycle. Soil Biology \& Biochemistry, 36, $267-278$. 